\title{
A Discourse Analysis of the Novel "Things Fall apart" and Two of Its Persian Translations at Micro and Macro Levels
}

\author{
Mandana Eftekhar Paziraie \\ Department of English, Faculty of Foreign Languages \\ Central Tehran Branch, Islamic Azad University, Tehran, Iran \\ Postal Code: 1484744947 \\ Tel: 98-919-127-8140Ｅ-mail: Meftekharp@gmail.com
}

Received: June 16, 2012

doi:10.5430/elr.v1n2p13
Accepted: July 10, 2012

Published: July 16, 2012

URL: http://dx.doi.org/10.5430/elr.v1n2p13

\begin{abstract}
This qualitative, quantitative, corpus-based, descriptive research, applied an eclectic approach to discourse analysis at the micro and macro levels, proposed by Halliday and Hasan (1976), Hatch (1992), and Farahzad (2008), to analyze the cohesive devices (endophoric references, conjunctions, and reiterations), constituent elements (characters, and the way they have been addressed), translators' judgments and footnotes, respectively, in the English novel "Things Fall apart" and its two Persian translations by Bahrami (2001), and Safavian (2009). The results showed that, Bahrami's translation was more cohesive compared to that of Safavian, at the micro level. At the macro level, the results showed that although both Bahrami and Savafian's translations were the same in terms of characters, Bahrami's translation transmitted the postcolonial theme, the theme flowing in the novel, more than Safavian's.
\end{abstract}

Keywords: Translation, Eclectic approach, Cohesive devices, Constituent elements, Discourse analysis, Postcolonialism

\section{Introduction}

Translation is mainly a change of form. In translation, a form is constantly changed into another, which is either the translator's own or another's language. Moreover, forms can be different types of language use, in other word; forms can be the spoken or written actual phrases, clauses, sentences or paragraphs. Larson (1984) believes that these forms are the surface structure of a language. In fact, translation has never been an isolated activity, there is always a text in which a text emerges and another one into which a text is transposed. Therefore, translation can be defined as the connection between the source and the target texts .

Furthermore, the source text may be composed of other texts, in turn. When the literary texts are considered, this issue becomes more significant. As Julia Kristeva (1966, as cited in Baron, 2010) explains, literary texts have special characteristics, may be one of the most obvious traits is "Intertextuality." Intertextuality states that the meaning of texts (literary ones especially) is shaped by other texts and in each text one can see the footprints of the other texts, so it implies that a literary text has never been an isolated one, instead, this text is related to the other texts and the meaning of this one is shaped and completed by other such texts, thus it can be claimed that a literary text is not a clean and pure one; it is polluted. A literary text is polluted in history, culture, power and other texts.

May be the idealform of a text for a reader, regardless of the type and genre of it, is the one, which is written in the reader's mother tongue, but in practice such a thing is sometimes a dream. Seen from one side of the coin, there is a need to read foreign texts and seen from the other, there is a lack of ability to read them. What is important here is a means to bridge these two. This means will be nothing but translation; however, translation itself has its own complexity and hardships, depending on the genre and type of the texts, which makes translation more or less complex. Taking the literary genre into consideration, and novels as a special instance in this genre, translation becomes more complex, since novelists use many literary and stylistic devices to make unfamiliar what seems to be familiar to the readers and present their literary works to their readers through this way.

Discourse analysis can be carried out within a variety of social science disciplines, including linguistics, sociology, and communication (McCarthy, 2005). Therefore, since discourse analysis can be applied to scrutinize the texts and decompose them, it is highly significant in translation. In fact, translators can use discourse analysis as a suitable tool 
to analyze the source texts in order to achieve better understanding of them, and the target texts, to evaluate the quality of their translated texts. Although, it seems that discourse analysis is the proper remedy for analyzing the complexity of literary texts, it should be stated that like any other means, discourse analysis has its own methodology, which should be learnt. Therefore, translators are faced with two challenges here. In fact, if they translate the texts without applying discourse analysis, they may not achieve better understanding of the text, so they may not be succeeded in the translation project. Moreover, if the translators apply a model of discourse analysis without being completely aware of the methodology, they may hurt the translation project.

As it was mentioned above, in this article, the researcher has applied an eclectic approach proposed by Halliday and Hasan (1976) at the micro level, and Hatch (1992) and Farahzad (2008) at the macro level, to analyze one English novel and its two Persian translations. By doing this, the researcher is aimed at connecting translation and discourse analysis, to provide a practical sample of applying discourse analysis for both translators and analysts. Moreover, the researcher is aimed at combining three models of discourse analysis, and introducing those three in the form of a single method for discourse analysis. In other words, the researcher is going to show how discourse analysis uncovers the layers of meaning and scrutinize it by decomposing the texts. Furthermore, the researcher is going to connect the postcolonial genre with translation, and investigates how discourse analysis can be applied to justify and explain the creation of post colonialism in the text and the transmission of which in the translation. In addition, it can be concluded that all the people who are engaged in the field of Translation studies and linguistics including: Translation teachers, students, analysts, and linguists can take the advantage of discourse analysis and the results of the present study.

\section{1 "Things Fall apart" as a Postcolonial Novel}

The history of postcolonial literature can be traced back to the beginning of the 20th century. At that time and by India's success in getting its independence, a new movement started in the history of colonized continents such as Africa, South America, Australia, and Asia. By the mid- $20^{\text {th }}$ century, some colonial and non-colonial authors created their works on colonialism and established the postcolonial literature. Achebe's "Things Fall apart" that is ranked as \#16 out of 100 top novels (Book Awards, 2009), and Fanon's Black Skin, White Masks, authored at 1950s (Bressler, 2007: 237). In fact, postcolonial literature is attached to all the works, which are done on the issue of colonialism, and since these works were created and written after the colonial ages, they were named "Postcolonial Literature." Yet, perhaps the key text in the establishment of postcolonial theory is Edward Wadie Said's Orientalism. In that text, he chastises the literary world for not investigating and taking seriously the study of colonization or imperialism (Bressler, 2007: 240). Years later a Polish author named Josef Conrad created one masterpiece named Heart of Darkness as a three-part series in 1899 in the Blackwood's magazine, which was then republished years later in 1902. It is widely regarded as a significant work of English literature and part of the Western canon. Little by little, postcolonial literature got much importance so that the works would become so well-known that many translators, Persian ones as well, started translating them in different languages in order to make them more tangible for their readers who did not know English. Since these works are translated in different languages, it can be very useful to analyze them. In fact, discourse analysis as a useful means allows its users to apply it and analyze the works both originals and translated ones, to find out the strategies and methodologies of the authors or the translators in detail.

The field of translation has been different researchers' area of interest. For instance, Joshua (as cited in Ray, 2008) analyzes the history of translation and explains that the process of translation gained form and order through the rendering of the Bible. The Arabs promoted translation greatly during the eighth, ninth, and tenth centuries. The sixteenth century is marked by the first theory for sense-to-sense translation. The seventeenth century is a great era for French classicism in which the translation of the French classics increased greatly in France between 1625 and 1660, and French writings were translated into English. The eighteenth century, was the time to clarify the sense of the text to the readers. Yet, the field of translation flourished with strange theories during the nineteenth century. The development of communication theory, the expansion of the field of structural linguistics and the application of linguistics effected significant changes in the principal and theory of translation during the twentieth century. Good literature written in any part of the world in any language is now made available to the rest of the world through translation.

Yet, according to LievenD'hulst (2001: 21, as cited in Bastin and Bandia, 2006: 1-2) "the history of translation has not received the attention, its merits in terms of research and cannot be compared to any other type of research in translation studies."

One issue that is important in the field of translation and in general in the context is discourse, this branch, which can be considered as the field of linguistics has won a variety of researchers' attention and interests. 
Although discourse analysis is not very old (it has been introduced for the first time in 1952), many scholars and theoreticians (Harris, 1952; Brown and Yule, 1983; Van Dijk, 1983) have considered this field of study in a variety of social science disciplines, such as semiotics, linguistics, anthropology, cognitive psychology, and translation studies. In addition, many researchers have conducted their research projects in this field and of course, they have limited their researches to one of its sub fields.

(Brown \& Yule 1983) believe that:

Discourse analysis reappeared in the late 1960s as a meeting point between, at least, four branches of the human sciences, such as linguistics, psychology, anthropology, and sociology and it is now used to handle issues at the intersection of sociolinguistics, psycholinguistics, and computational linguistics. (As cited in Genc et al, 2006: 135-136)

(Shiffrin et al., as cited in Alba-Juez, 2009), states that all the definitions of discourse analysis fall into these three categories:

1) Anything beyond the sentence

2) Language use

3) A broader range of social practice that includes non-linguistic and non-specific instances of language. (2009:1)

Gee (2010: 116) states "a discourse analysis is based on the details of speech (and gaze and gesture and action) or writing that are arguably deemed relevant in the context and that are relevant to the arguments the analysis is attempting to make."

Yet, Van Dijk (1983) believes that discourse is analyzed at different levels, and each level has its own sub-levels. For instance, phonology is regarded as one level of discourse and intonation, and the structure of sounds is considered as some sub-level of phonology. Through this example, Van Dijk (1983) states that when morphology is regarded as one analyzing the level of discourse, it belongs to one larger group that he called "surface structure." Yet, more interesting issue is that similar to levels, units can be recognized for discourse analysis as well: individual words, the various structures of the clause, whole sentences, sequences of sentences (paragraphs), or the whole discourse. In order to illuminate what he says, he uses an example and states "for example, the whole theme, or topic of the discourse can be studied only through semantics not lexical items or sentences." (1983: 2)

It will be useful to look at the discourse analysis approaches:

Authors such as Schiffrin (1994) and Leech (1983) distinguish between two main approaches: 1) formal approach where discourse is defined as a unit of language beyond the sentence, and 2) the functional approach, which defines discourse as language use. Z. Harris $(1951,1952)$ was the first linguist to use the term discourse analysis and he was a formalist: he viewed discourses the next level in a hierarchy of morphemes, clauses, and sentences. (Alba-Juez, 2009: 13)

Solhjoo (2009) also believes that discourse, includes larger units than sentences. He believes that if the rules of discourse are applied, the sentences in a paragraph can be stated more concretely. It makes the reader and the hearer move from one sentence to another easier.

Although for Harris (1952) discourse was a higher level than sentences, he used discourse in its expanded meaning. Instead, discourse was an umbrella term to them, which not only involved the propositional content, but also the social, cultural and contextual contexts.

Halliday and Hasan (1976, as cited in Butler, 2003) recognize three types of reference as one of the grammatical cohesive devices elements: personal, demonstrative, and comparative. Personal reference is achieved through personal pronouns, possessive pronouns, and determiners. However, they believe that endophoric personal references are only cohesive. Moreover, they believe that only endophoric demonstratives are inherently cohesive.

It is also interesting to know that "discourse analytical approaches take as their starting point the claim of structuralist and poststructuralist linguistic philosophy that our access to reality is always through language." (Jorgenson et al., 2002:4)

Van Dijk (1983) believes that by analyzing the stories from the sociolinguistics point of view the sociolinguists found out that storytelling has not only different structural categories in different cultures, but also it puts specific constraints on who can tell what to whom under what circumstances or similarly, on how greeting rituals or other speech events take place in such cultures. 
Hatch (1992) emphasizes on the stories components and believes that the following elements are vital for analyzing the macro structure in stories. The elements are in four numbers that can be summarized as follows;

- Setting of the story (time and place orientation)

- Characters

- The aim of the story

- Statement of the problem

- Resolution

- Conclusion

Therefore, it can be concluded that all the stories have plots. "Plot is the temporal and causal arrangement of events in a story that is connected to the character. Characters are defined by the plot, and the plot becomes evident as characters act and interact." (Aune, 2003: 361).

Narrative theory is obliged to see things very differently. In fact in order to discover what really happened, it will be necessary to sift through the narrator's account of what happened in the world of story what 'really happened', can be reached only through the discourse that presents it. (O'Neill, 1994)

O'Neill (1994) also believes that the stories, which seem completely vague and solid, are examined as closely as possible to become more diaphanous. In other words it can be conveyed that for the external observer (the reader, for example) the world of the story seems unreal and too far away from the real world; while for the internal actor, it reveals as a world that is completely provisional, unstable and inescapable. Some narratives start by telling the events generated solely while some others are not. In the first case, there are some figures, which have been created such as Rostam and Sohrab, while in the other ones the figures had existed before they were mentioned; for instance, all the autobiographies, historical narratives, and biographies. As an example of this kind, consider SohrabSepehri's biography in which it can be said that he had existed before this, while in the case of Rostam and Sohrab, why they are created is the issue. Also such a thing can be found in the names of places too, where the events of the narrative are taking place; Tooran (Shahnameh) is completely fictional while the real name of a place such as Kashan (a city in Iran) can be mentioned as two examples to clarify what is meant by real place and imaginary ones. The world of the story, is and must remain not only an abstraction but also essentially inaccessible to entities external to it. We can never penetrate as readers into this world. Any attempt to isolate the story from its discourse 'war and peace tells the story of...' -simply results in another telling of the story. All we can ever do as readers, other than theoretically is paraphrase, re-tell, and provide another discourse. (O'Neill, 1994: 36)

Furthermore, there are scholars (Young, 2003; Loomba, 2005; Bressler, 2007, Hawley, 2001), to name a few who have discussed postcolonialism. Hawley (2001: 142) studies postcolonialism and states that "postcolonial discourse that focuses on text written in English veer toward "academic neocolonialism." The focus on the subaltern frequently has excluded works done by the subaltern; vernacular and popular cultural texts that embody a literature of self-awareness continue to remain ghettoized."

Moreover, Hawley considers the Achebe's writings and believes that Achebe's purpose in writing has always been to provide for African readers images of themselves and to overturn the notion that writing and literature are concepts that come to Africans only from outside. Particularly, in his novels, Achebe tries to portray the embedded social worlds in Igboland and Nigeria that span the period from the late $19^{\text {th }}$ to the late $20^{\text {th }}$ centuries. As an example, his two novels "Things Fall Apart and Arrow of God" portray the incursion of colonial rule in the world of the Igbo. (Hawley, 2001: 4)

Yet in other research that has been done on the concept of postcolonialism specifically, the researcher has analyzed Things Fall Apart and she has stated that this Achebe's novel as an African novel written in English depends on his use of Ibo words to draw its reader's attention to the problematic relationship between language and cultural identity. (Iyasere 1998: 77, as cited in Tajilorou, 2007)

Different scholars have conducted their studies on postcolonialism so far. One of these researchers is Pandey (1999).Pandey analyses the postcolonial novels and tries to scrutinize them to find out the sketch or the anatomy of these kinds of novels as much as possible. During the analysis, Pandey (1999: 22) explains that style stands in the first place of attention, after that one can study the structure and plot of these novels; "Style is but one aspect of the novel, [...]. More so than structure and plot, which in the end remain fairly conventional, it is the social themes to deal with by this novelist" (1999: 22). 
One of the researchers who studied narrative genre was (Labov, 1972: 354-396, as cited in Schiffrin, Tannen\& Heidi E. Hamilton, 2001) who believed that any narrative is composed of two narrative clauses. A narrative clause is one that cannot move without changing the order in which events must be taken to have occurred. Therefore, it implies that for Labov, narrative is not any talk in which a sequence of clauses is matched to a sequence of events, which actually occurred.

The other research, which was conducted in the field of discourse analysis, is that of Labovet al. (1967, as cited in Schiffrin, 2001) which were done about "PEN" (Personal Experienced Narrative). In this research, they have gathered fourteen stories people narrated about their personal experiences mostly the embarrassing ones, and then they analyzed the discourse in these narratives based on a "formal" approach. According to what they reported, a clause in PEN can have two functions; referential and evaluative; referential clauses, have to do with what the story is about events, characters, and setting. Evaluative clauses, on the on the other hand, have to do with why the narrator is telling the story and why the audience should listen to it.

Another research that has been conducted on the issue of discourse analysis is that of Farahzad et al (2009) in which through the application of the CDA, the researcher intended to shed light on various ideological impacts exerted by different translators of the American novel, "Gone with the Wind." Since this research is practiced at two micro and macro levels, the researcher has applied omission, addition, and the literal translation at the micro level; however, at the macro level, the researcher has analyzed the translators' judgments and footnotes regarding the proto-text (ST) in the light of the socio-historical conditions of production and reception of the text. At the end, the researcher has concluded that these factors have affected the translation product at different levels and the translations are different regarding these factors.

\section{Methodology}

Through the application of DA, the researcher intended to shed light on variouscohesive devices and details of the texts at micro and macro levels, exerted by different translators of the novel "Things Fall apart." This article addresses the following questions:

1) Regarding discourse analysis in Hatch's (1992) viewpoint at the macro level, what are the similarities and differences between the characters in the Persian translations of Achebe's "Things Fall Apart"?

2) Regarding discourse analysis at the micro levelinHalliday and Hasan's (1976) viewpoints, what are the differences between the endophoric reference, conjunction, and reiteration in the Persian translations of Achebe's "Things Fall Apart"?

3) What are the differences between the themes of postcolonialism between the Persian translations of Achebe's "Things Fall apart"?

\section{Corpus Selection}

The corpora of the study consisted of 12 chapters, selected randomly out of 25 chapters of the "Things Fall apart," written by Chinua Achebe (1958) along with its Persian translations "جهيز فرو مى ريزد [HameChizForooMirizad]", and هده قيز فرو مى ياثند" [HameChizForooMipashad]" produced by two different translators.

The first translation of "Things Fall apart,"[HameChizForoMipashad] was rendered by GolrizSafavian in 1388 Iranian calendar (2009), the second one [HameChizForooMirizad] by Ali AsgharBahrami in 1380 Iranian calendar (2001).

\section{Data collection}

The study mainly focused on contrasting the source text with its translated texts in different periods to find the cohesive elements and constituent elements named in the research questions as well as the postcolonial theme of the production of the source and translated texts. In this regard, any manipulation in the translations of certain features in this novel, comparable to those existing in the original text, was precisely analyzed within the DA framework developed by Halliday and Hasan (1976)atthe micro level, and Hatch (1992)at the macro level.

For this purpose, the researcher studied and investigated any endophoric references (personal references, demonstratives, and comparatives), conjunctions (additives, adversatives, and casuals), reiterations (synonym/near-synonyms and superordinate), which had occurred during the process of translation in 12 chapters out of 23 chapters of the book. She also probed into the characters of the story and analyzed them separately to find any probable difference between the source texts with its translations. In addition, she studied all the chapters at the macro level. Finally, the researcher analyzed the collected data within DA framework. 


\section{Results and Discussion}

\subsection{Analysis at Micro level}

Table 1 displays some of the significant examples of endophoric references, conjunctions, and reiterations, which occurred in the two translations of "Things Fall apart." In this table, the bold parts shown in translations indicate the endophoric references, the italicized parts shown in the two translations indicate the conjunctions, and the underlined parts indicate reiterations.

Table 2 shows the frequency and percentage of endophoric references, conjunctions, and reiterations by the separation of sub-categories occurred within "Things Fall apart" and its translations.

Accordingto the above table, from the total number of 1,884 cases of cohesive devices in Safavian's translation (2009), 964 cases (equal to 51\%) belong to endophoric personal, 184 cases (equal to $10 \%$ ) to endophoric demonstrative, 51 cases (equal to 3\%) belong to endophoric comparative. Moreover, 478 cases (equal to $25 \%$ ) belong to additive, 97 cases (equal to $5 \%$ ) belong to adversative, and 50 cases (equal to $3 \%$ ) belong to the causal. Finally, 35 cases (equal to $2 \%$ ) belong to synonym/near-synonym, and 25 cases (equal to $1 \%$ ) belong to superordinate.

Moreover, from the total number of 1,841 cases of cohesive devices in Bahrami's translation (2001), 523 cases (equal to $28 \%$ ) belong to endophoric personal, 282 cases (equal to $15 \%$ ) belong to endophoric demonstrative, and 29 cases (equal to $2 \%$ ) belong to endophoric comparative. In addition, 818 cases (equal to $44 \%$ ) belong to additive, 119 cases (equal to 6\%) belong to adversative, and 22 cases (equal to 1\%) belong to the causal. Finally, 30 cases (equal to $2 \%$ ) belong to synonym/near-synonym, and 18 cases (equal to $1 \%$ ) belong to superordinate.

According to the results of the total number of 2,878 cases of cohesive devices in Achebe's text (1986), 1787 cases (equal to $62 \%$ ) belong to endophoric personal, 120 cases (equal to 4\%) belong to endophoric demonstrative, and 181 cases (equal to 6\%) belong to endophoric comparative. Moreover, 589 cases (equal to 79\%) belong to additive, 122 cases (equal to $16 \%$ ) belong to adversative, and 38 cases (equal to 5\%) belong to the causal. Finally, 20 cases (equal to $49 \%$ ) belong to synonym/near-synonym, and 21 cases (equal to $51 \%$ ) belong to superordinate.

\subsection{Analysis at Macro Level}

At this level, the researcher studied the numbers of characters in the light of different versions of production and comprehension of the text. Comparison of characters reappeared in the two translations of "Things Fall apart."

The following table shows the frequency of characters given in the form of "by their names," and "by their jobs," and "by their names and titles" The letter (F) represents frequency and (P) represents percentage.

As the results show, both the total number and the frequency of each category is the same among the source and translated texts, and there is no difference between the Persian translated texts in terms of characters.

As it was stated earlier, since "Things Fall apart" is elite postcolonial novel, at this level, the researcher is going to apply Farahzad's framework (2008) to analyze the transmission of postcolonialism through the translated texts. As Farahzad (2008) believes in the texts like the ones under the study, there are some places, where the translators use some ways to convey a meaning to the target text readers. For example, the Persian translators have introduced the issue of postcolonialism in the begging of the books before starting the translation, in order to ready the readers' mind with the current theme of the English novel. Moreover, since Achebe has used various specific names including the names of dishes, fruits, customs, the Persian translators have used footnotes wherever, they felt it was necessary to explain the words more. Farahzad (2008) names these considerations as "translator's judgments."

The last part of the "finding and result" in the present article analyzes these judgments.

\subsection{Comparison of the translator's judgments of "Things Fall apart"}

The two translators are different in their approaches towards the source text mainly in terms of amount and content.

Bahrami (2001) allocated fifteen pages entitled "preface" or [pishgoftar], in which he gave detailed information about the source text writer's birthplace, education, marriage, occupations, and his status in the African literary canon. He further referred to the Margaret Wrong Memorial and National Award of Nigeria Prizes, which went to him (the author) in 1959.

Safavian (2010) allocated six pages entitled "translator's note," or [yaddasht e motarjem], in which she gave some general information about the source text writer's birthplace, education, and works. 


\subsection{Comparison of the Translations' Footnotes in "Things Fall apart"}

The following table shows the frequency of footnotes given in the form of "only named in English," "only Persian explanation," and "English names with Persian explanation." The letter (F) represents frequency and (P) represents percentage.

The above table indicates that from the total of 48 footnotes, which were found in Safavian's translation (2009), 48 cases (equal to 100\%) belong to only name in English, and no case relates to only Persian explanation and English names with Persian explanation.

Furthermore, from the total number of 63 cases of footnotes, which were found in Bahrami's translation (2001) 36 cases (equal to 57\%) belong to only name in English, 5 cases (equal to 8\%) belongs to only Persian explanation, and 22 cases (equal to 35\%) belong to English names with Persian explanation.

\section{Discussion}

\subsection{Micro level: endophoric reference, conjunction, and reiteration}

As it was presented in the table, the most significant amount of endophoric personal reference relates to Safavian's rendition (2009), while the most significant amount of endophoric demonstrative relates to Bahrami's rendition (2001), and the most significant amount of endophoric comparatives relates to Safavian's rendition (2009). These results show that Safavian (2009) used more amount of reference in her translation than Bahrami (2001). However, in terms of conjunction, she used less amount of conjunction than Bahrami (2001). Therefore, regarding the grammatical cohesive devices studied in the article, it cannot be stated that which translator was more coherent in the rendition.

Moreover, the most significant number of synonym/near-synonym and superordinate relate to Safavian's rendition (2009). Therefore, regarding the lexical cohesive devices studied in this article, it can be concluded that Safavian had a more coherent translation.

\subsection{Macro level: Characters}

As it was presented in the table 5, the most significant amount of characters is related to the category of "by their names," which is the same for the both translators and the writer. Moreover, the least amount of characters is related to the category of "by their names and titles," which is the same for the both translators, and the writer.

In addition, the two translators used as many characters as the original writer used. This shows that both translators had similar opinions toward use of characters. Therefore, it can be concluded that at the macro level, the two translations are similarly coherent and none of these two texts have coherently superior to the other.

\subsection{Postcolonial level: Judgment}

The prefaces and introductions written to these two translations clearly show their understanding of the source text writer, and their effort to introduce the writer's work to the readers.

In this regard, Bahrami's rendition (1389/2001) produced more detailed information about the source text than Safavian (1388/2009) did. It shows that Bahrami was more interested in giving information to the readers than Safavian, or Bahrami was more knowledgeable on the issue of the book than Safavian.

Moreover, since Bahrami (2001) provided more information on the issue of colonialism and the novel, which is written on this issue as well, it can be concluded that he had transmitted more information on postcolonialism in his rendition than Safavian (2009).

\subsection{Footnote}

According to table 6, and out of the total number of 48 cases of footnotes that Safavian (2009) provided, all the 48 cases (equal to $100 \%$ ) relate to only name in English. It shows that she was not interested in providing the readers with any Persian information or any extra Persian translation. In addition, since the words for which she gave footnotes are all about the traditions and especial customs of the characters, it can be stated that Safavian (2009) did not transmit the meaning of postcolonialism through her translation.

However, Bahrami (2001) used 36 cases out of 63 cases of footnotes on "only English names," while he used 22 cases on "English names with Persian explanation," and finally 5 cases on only Persian explanation. These results show that Bahrami (2001) was more interested in providing the readers with all kinds of footnotes, or he was more knowledgeable in giving information. Moreover, since the words for which footnotes are provided are words on 
special customs and tradition that have postcolonial connotation, it can be concluded that Bahrami (2001) transmitted the issue of postcolonialism more than Safavian.

Finally, according to the results, one can conclude that the postcolonial theme in the story, which is hidden behind the words of the story, that translator who had and presented a better understanding of the words and the story to the reader was more successful in transmission of postcolonialism through translation. Therefore, since Bahrami (2001) included a stronger preface and presented more footnotes in his translation, he was more successful than Safavian (2009) in transmitting of postcolonialism.

\section{Conclusion}

Comparison of the micro and macro levels gave rise to interesting results, proving significant differences at the micro level (i.e. Endophoric personal, demonstrative, and comparative references, additive and adversative conjunctions, and synonym/near-synonym and superordinate) and macro level (i.e. Characters, and they way they have been addressed). Moreover the results included differences between translator's judgments and footnotes) in these translations.

Bahrami's translation exhibits the highest degree of cohesive devices. In his rendition, which was carried out in (1380/2001), Bahrami has used more additive and adversative conjunctions and higher numbers of demonstrative references.

At the macro level, the analysis of constituent elements of the novelclearly showed that the translators had the same idea toward using the characters.

The analysis of the prefaces and introductions written to these two translations clearly shows the difference between levels of interest in giving the information to the readers and levels of comprehending the postcolonial spirit in the source text.

In his short preface to the book, Safavian (2009) was mostly active in explaining only a brief history of colonialism and a short biography of the source text writer's life, while Bahrami's preface (2001) includes the translator's full understanding of the source text and the postcolonial theme in it.

Regarding the footnotes given by the translators, it is worth saying that the highest amount belongs to Bahrami (2001), whose attempt at providing readers with useful information as footnotes.

In this paper, the researcher applied DA to analyze one English novel "Things Fall apart" and two of its Persian translations at micro and macro levels. Moreover, the researcher analyzed footnotes and prefaces the translators provided to investigate the transmission of postcolonialism through the translations.

By applying this model of the DA, the Translation teachers and students can analyze the translated texts accurately and understand how much their translations are coherent. Moreover, the teachers and students can analyze the books translated before by different translators, in order to find those that are more coherent. Finally, syllabus designers can include different models of DA in different Translation courses by which they assist students to present translations that are more accurate.

The researcher has provided some suggestions for those who are interested in conducting their research in DA field;

1) What are the similarities and differences between substitution in the Persian translations of the novel "Things Fall apart'from the perspectives ofHalliday and Hasan (1976)?

2) What are the similarities and differences between the constituent elements in the two Persian translation of Achebe's novel "Things Fall apart" from the perspective of Hatch (1992)?

3) What are the differences among the two Persian translations of Achebe's novel "Things Fall apart" in terms of addition, omission and passive/active structures?

\section{References}

Achebe, Ch. (1958). Things Fall Apart Expanded Edition with Notes. South Africa: William Heinemann Ltd.

Alba-Juez, L. (2009). Perspectives on Discourse Analysis: Theory and Practice. UK: Cambridge Scholars Publishing.

Aune, D. E. (2003).The Westminster Dictionary of New Testament and Early Christian Literature. USA: Library of Congress.

Bahrami, A. (2001). HameChizForoMipashad.[Things Fall apart]. Tehran: JavanehRoshd. 
Baron, S. (2010). Strandentwining Cable:Joyce, Flaubert, and Intertextuality. New York: Oxford University Press.

Bastin, L. G, \&Bandia, F. P. (2006).Charting the Future of Translation History. Canada: Universityof Ottawa Press.

Bressler, Ch. E. (2007). Literary Criticism: An Introduction to Theory and Practice ( $4^{\text {th }}$ Ed.). New Jersey: Pearson.

Book awards: Newsweek's Top 100 Books: The Meta-List. (2009, June 12). Retrieved December, 10, 2011, from http://www.librarything.com/bookaward/Newsweek\%27s+Top+100+Books:+The+Meta-List.

Brown, G., \& Yule, G. (1984).Discourse Analysis. Cambridge: Cambridge University Press.

Butler, Ch. (2003). Structure and Function: A Guide to Three Major Structural-Functional Theories: Part 2. USA: John Benjamins Publication Co.

Farahzad, F. (2008). Translation Criticism: A CDA Approach. In Translation Studies Quarterly, Vol. 6. No. 24..pp. 39-47.

Farahzad, F.,\&MadaniGivi, F. (2009). Ideology and Translation: A Case Study. In Translation Studies Quarterly, Vol. 7, No. 26.,pp. 11-30

Gee. P. J. (2010). An Introduction to Discourse Analysis: Theory and Method ( $3^{\text {rd }}$ Ed.). UK: Taylor \& Francis e-library.

Genc, B., \&Boda, E. (2006).Oral Narrative Discourse of Anaphoric References of Turkish EFL Learners.Reading Matrix.Vol. 6, No. 2., pp. 135-143

Halliday, M.A.K., \&Hasan, R. (1976).Cohesion in English. London: Longman.

Hatch, E. (1992).Discourse and Language Education. Cambridge: Cambridge University Press.

Hawley, J. Ch. (2001). Encyclopedia of Postcolonial Studies. USA: Library of Congress Cataloging-in Publication Data.

Jorgenson, M., \& Philips, L. (2002).Discourse Analysis as Theory and Method. London and Thousand Oaks and New Delhi: Sage.

Larson, M. L. (1984). Meaning-based Translation. USA: University Press of America.

Loomba, A. (2005). Colonial/Postcolonialism. USA \& Canada: Routledge.

McCarthy, M. (2005).Discourse Analysis for Language Teacher. United Kingdom: Cambridge University Press.

O’Neill, P. (1996). Fictions of Discourse: Reading Narrative Theory. Canada: University of Toronto Press.

Pandey, S. N. (1999). Writing in a Post-Colonial Space. New-Delhi: Atlantic Publishers and Distributors.

Ray, M. K. (2008). Studies in Translation; Translation: Its Brief History and Theory $\left(2^{\text {nd }}\right.$ rev. Enlarged Ed.). India: Nice Printing Press, Delhi.

Safavian, G. (2009). HameChizForoMirizad. [Things Fall apart]. ( $2^{\text {nd }}$ Ed). Tehran: Soroush.

Schiffrin, D., Tannen, D., \& Hamilton, H. E. (2001). The Handbook of Discourse Analysis. UK: Blackwell Publishers.

Solhjoo, A. (2009). GoftmanvaTarjomeh.[Discourse and Tranlastion].Tehran: NashrMarkaz.

Tajilrou, M. (2007).A Postcolonial Study of Achebe's Things Fall Apart and Arrow of God.Unpublished master's thesis, Islamic Azad University, Central Tehran Branch, Iran.

Van Dijk, T. A. (1983). Discourse Analysis: Its Development and Application to the Structure of News, Journal of Communication. Vol. 33.No. 2. pp. 20-43. http://dx.doi.org/10.1111/j.1460-2466.1983.tb02386.x

Young, R. (2003). Postolonialism: A Very Short Introduction. New York: Oxford University Press Inc. 
Table 1.Endophoric references, conjunctions, and reiteration in the two translations of "Things Fall apart"

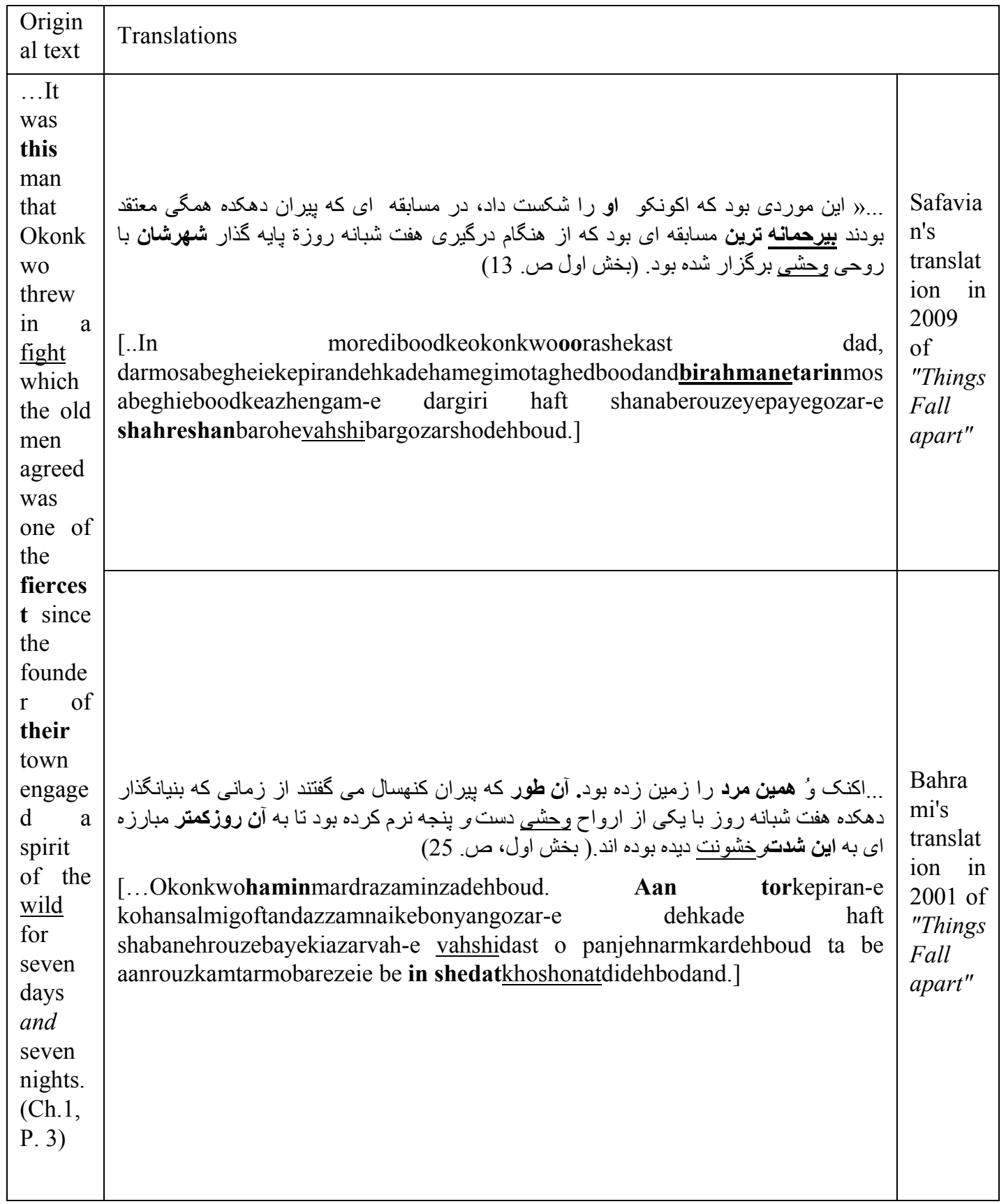


Table 2. Frequency and percentage of grammatical and lexical cohesive devices studied in the two translations of "Things Fall apart"

\begin{tabular}{|c|c|c|c|c|c|c|c|}
\hline \multicolumn{2}{|l|}{ Translators } & \multicolumn{2}{|c|}{$\begin{array}{l}\text { Safavian } \\
(2009)\end{array}$} & \multicolumn{2}{|c|}{$\begin{array}{l}\text { Bahrami } \\
(2001)\end{array}$} & \multicolumn{2}{|c|}{$\begin{array}{l}\text { Achebe } \\
\text { (1958) }\end{array}$} \\
\hline & & F1 & $\mathrm{P} 1$ & F1 & $\mathrm{P} 1$ & F1 & $\mathrm{P} 1$ \\
\hline \multirow{8}{*}{$\begin{array}{l}\text { Frequenc } \\
\text { y/Percent } \\
\text { age of } \\
\text { Subcateg } \\
\text { ories }\end{array}$} & $\begin{array}{l}\text { Endophoric } \\
\text { Personal }\end{array}$ & 964 & $\begin{array}{l}51 \\
\%\end{array}$ & 523 & $\begin{array}{l}28 \\
\%\end{array}$ & 1787 & $\begin{array}{l}62 \\
\%\end{array}$ \\
\hline & $\begin{array}{l}\text { Endophoric } \\
\text { Demonstrat } \\
\text { ive }\end{array}$ & 184 & $\begin{array}{l}10 \\
\%\end{array}$ & 282 & $\begin{array}{l}15 \\
\%\end{array}$ & 120 & $4 \%$ \\
\hline & $\begin{array}{l}\text { Endophoric } \\
\text { Comparativ } \\
\text { e }\end{array}$ & 51 & $3 \%$ & 29 & $2 \%$ & 181 & $6 \%$ \\
\hline & Additive & 478 & $\begin{array}{l}25 \\
\%\end{array}$ & 818 & $\begin{array}{l}44 \\
\%\end{array}$ & 589 & $\begin{array}{l}79 \\
\%\end{array}$ \\
\hline & $\begin{array}{l}\text { Adversativ } \\
\mathrm{e}\end{array}$ & 97 & $5 \%$ & 119 & $6 \%$ & 122 & $\begin{array}{l}16 \\
\%\end{array}$ \\
\hline & Causal & 50 & $3 \%$ & 22 & $1 \%$ & 38 & $5 \%$ \\
\hline & $\begin{array}{l}\text { Synonym/n } \\
\text { ear-synony } \\
\mathrm{m}\end{array}$ & 35 & $2 \%$ & 30 & $2 \%$ & 20 & $\begin{array}{l}49 \\
\%\end{array}$ \\
\hline & $\begin{array}{l}\text { Superordin } \\
\text { ate }\end{array}$ & 25 & $1 \%$ & 18 & $1 \%$ & 21 & $\begin{array}{l}51 \\
\%\end{array}$ \\
\hline \multicolumn{2}{|c|}{ Total number } & \multicolumn{2}{|c|}{1884} & \multicolumn{2}{|c|}{1841} & \multicolumn{2}{|l|}{2878} \\
\hline
\end{tabular}

Table 3.Frequency and percentage of the number of charactersin the two translations of "Things Fall apart" along with the original text

\begin{tabular}{|c|c|c|c|c|c|c|c|}
\hline \multicolumn{2}{|l|}{ Translators } & \multicolumn{2}{|c|}{$\begin{array}{l}\text { Safavian } \\
(2009)\end{array}$} & \multicolumn{2}{|c|}{$\begin{array}{l}\text { Bahrami } \\
(2001)\end{array}$} & \multicolumn{2}{|c|}{$\begin{array}{l}\text { Achebe } \\
\text { (1958) }\end{array}$} \\
\hline & & $\mathrm{F} 1$ & $\mathrm{P} 1$ & F1 & P1 & $\begin{array}{l}\mathrm{F} \\
1\end{array}$ & $\mathrm{P} 1$ \\
\hline \multirow{3}{*}{$\begin{array}{l}\text { Frequency/Per } \\
\text { centage of } \\
\text { Subcategories }\end{array}$} & $\begin{array}{l}\text { By their } \\
\text { names }\end{array}$ & 18 & $86 \%$ & 18 & $86 \%$ & 18 & $86 \%$ \\
\hline & $\begin{array}{l}\text { By their } \\
\text { jobs }\end{array}$ & 1 & $5 \%$ & 1 & $5 \%$ & 1 & $5 \%$ \\
\hline & $\begin{array}{l}\text { By their } \\
\text { names } \\
\text { and } \\
\text { titles }\end{array}$ & 2 & $10 \%$ & 2 & $10 \%$ & 2 & $10 \%$ \\
\hline \multicolumn{2}{|l|}{ Total number } & 20 & $100 \%$ & 20 & $100 \%$ & 20 & $100 \%$ \\
\hline
\end{tabular}


Table 4. Frequency and percentage of footnotes in the two translations of "Things Fall apart"

\begin{tabular}{|c|c|c|c|c|c|}
\hline \multicolumn{2}{|l|}{ Translators } & \multicolumn{2}{|c|}{$\begin{array}{l}\text { Safavian } \\
(2001)\end{array}$} & \multicolumn{2}{|c|}{$\begin{array}{l}\text { Bahrami } \\
(2009)\end{array}$} \\
\hline & & $\begin{array}{l}\mathrm{F} \\
1\end{array}$ & $\mathrm{P} 1$ & $\mathrm{~F} 1$ & P1 \\
\hline \multirow{3}{*}{$\begin{array}{l}\text { Frequency/Per } \\
\text { centage of } \\
\text { Subcategories }\end{array}$} & $\begin{array}{l}\text { Only named in } \\
\text { English }\end{array}$ & 48 & $\begin{array}{l}100 \\
\%\end{array}$ & 36 & $57 \%$ \\
\hline & $\begin{array}{l}\text { Only Persian } \\
\text { explanation }\end{array}$ & 0 & 0 & 5 & $8 \%$ \\
\hline & $\begin{array}{l}\text { English names } \\
\text { with } \\
\text { explanation }\end{array}$ & 0 & 0 & 22 & $35 \%$ \\
\hline \multicolumn{2}{|l|}{ Total number } & \multicolumn{2}{|l|}{48} & \multicolumn{2}{|l|}{63} \\
\hline
\end{tabular}

